Polar Biol (1985) 5:23-30

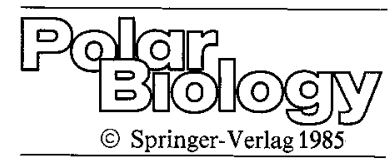

\title{
Multivariate Statistical Analysis of Net Diatom Species Distributions in the Southwestern Atlantic and Indian Ocean
}

\author{
E. Theriot* and G. Fryxell \\ Department of Oceanography, Texas A\&M University, College Station, TX 77843, USA
}

Received 25 September 1984; accepted 15 April 1985

Summary. Vertical net haul diatom assemblages from near South Georgia, and from between Africa and Antarctica, were examined and compared. Variation among South Georgia stations was examined by principal component, cluster and canonical discriminant analyses. Diatom distributions provide evidence for at least two distinct water masses. The region north of the island is characterized by neritic, temperate diatoms and by an assemblage with low species diversity. The region south of the island is characterized by oceanic, antarctic species and relatively high species diversity. The regions are most distinct to the west of the island, intergrading east of the island. Within the north-south division, five station groupings were detected on the basis of distribution of dominant net diatoms. By comparing classical species ecological categorizations to results of principal component analysis, a "neritic-oceanic" factor was identified from net diatom distributions. This factor was common to both areas in spite of the fact that Biscoe and Agulhas collections were from different seasons.

\section{Introduction}

Most phytoplankton studies of the antarctic region have been based on samples taken from an array of stations widespread in time and space (e.g. Karsten 1906, Mangin 1922; Hendey 1937; Hart 1942; Hustedt 1958; Frenguelli and Orlando 1958; Kozlova 1966; Hasle 1969; Van de Spoel et al. 1973). However, Hardy and Gunther (1935) focused on the net plankton assemblage of transects radiating from South Georgia (S. Georgia). Hendey's (1937) and Hart's (1942) reports were also derived in part from stations near S. Georgia.

Hardy and Gunther (1935) reported that Weddell Sea water and Bellingshausen Sea water were mixing in the

* Current address: Great Lakes Research Division, University of Michigan, Ann Arbor, MI 48109, USA vicinity of S. Georgia. Hardy (1967) suggested that the high phytoplankton standing stock at S. Georgia resulted from each water mass contributing trace substances in which the other was deficient. Perhaps as a consequence of this area's productivity and apparently dynamic habitat, the island's waters reportedly have an unusual net diatom assemblage. Hart (1942) classified antarctic diatoms on the basis of their temporal and spatial distribution. He considered certain taxa, especially those with neritic distributions, to be characteristic of S. Georgia waters. However, all ecological groups reached their greatest abundance in the S. Georgia area (Hart 1942).

This study compares net diatom assemblages from samples taken during a three week survey of a grid of stations centered on S. Georgia during the austral spring of 1981. Species distributions near S. Georgia are compared with samples taken later in the same year in the southwestern Indian Ocean, facilitating characterization of the $\mathrm{S}$. Georgia assemblage independent of literature ecological classifications. Hart's (1942) finding that the S. Georgia zone assemblage has both neritic and oceanic elements is confirmed, and comments are made on attempted ecological grouping of antarctic diatoms.

\section{Materials and Methods}

The grid around South Georgia of Fig. 1 was sampled during the first leg of the RRS John Biscoe cruise 3, 24 November - 19 December 1981, by the British Antarctic Survey (stations and samples hereafter referred to as Biscoe). Thirty-five $\mu \mathrm{m}$ mesh vertical net hauls were made from a depth of $100 \mathrm{~m}$, water depth and weather conditions permitting. Additional $35 \mu \mathrm{m}$ mesh vertical net hauls, from $200 \mathrm{~m}$ to the surface, were analyzed from selected stations sampled during 16 February -5 March 1981 between South Africa and Antarctica by the South African vessel Agulhas (Fig. 2).

All net samples reported in this paper were cleaned by the method of Simonsen (1974) and mounted on permanent glass slides in Hyrax. At least 300 valves were tallied from each slide. If 20 species were not recorded after 300 valves then counting was continued until either 20 species or 500 valves were tallied. Species abundances were calculated 
Table 1. Species occurring in half or more of either the Biscoe or Agulhas stations in order of frequency of occurrence in Biscoe samples. List compiled from cleaned net tows

\begin{tabular}{|c|c|c|c|}
\hline \multirow[t]{2}{*}{ Code } & \multirow[t]{2}{*}{ Species } & \multicolumn{2}{|c|}{$\begin{array}{l}\% \text { frequency of } \\
\text { occurence }\end{array}$} \\
\hline & & Biscoe & Agulhas \\
\hline CRCRI & Corethron criophilum & 100.0 & 100.0 \\
\hline NIKER & Nitzschia kerguelensis & 93.8 & 100.0 \\
\hline CHCUR & Chaetoceros curvisetum & 85.9 & 50.0 \\
\hline DSSPE & Distephanus speculum & 84.4 & 91.7 \\
\hline THLEN & Thalassiosira lentiginosa & 84.4 & 50.0 \\
\hline NICYL & Nitzschia cylindrus & 81.2 & 100.0 \\
\hline RHHEBSEM & Rhizosolenia hebetata fo. semispina & 81.2 & 25.0 \\
\hline NILIN & Nitzschia lineola & 79.7 & 91.7 \\
\hline THTUM & Thalassiosia tumida & 76.6 & 33.3 \\
\hline THGRA & Thalassiosira gravida & 75.0 & 0.0 \\
\hline NISUB & Nitzschia sublineata & 73.4 & 25.0 \\
\hline TXLON & Thalassiothrix longissima & 71.9 & 91.7 \\
\hline CHCRI & Chaetoceros criophilum & 71.9 & 66.7 \\
\hline CHATL & Chaetoceros atlanticum & 70.3 & 58.3 \\
\hline NIPSE & Nitzschia pseudonana & 68.8 & 100.0 \\
\hline NIANG & Nitzschia angulata & 64.1 & 66.7 \\
\hline NICUR & Nitzschia curta & 59.4 & 91.7 \\
\hline ODWEI & Odontella weissflogii & 57.8 & 0.0 \\
\hline THSCO & Thalassiosira scotia & 56.2 & 8.3 \\
\hline EUANT & Eucampia balaustium & 54.7 & 50.0 \\
\hline CDOCU & Coscinodiscus oculus-iridis & 54.7 & 16.7 \\
\hline PLDIR & Pleurosigma directum & 54.7 & 0.0 \\
\hline NIRIT & Nitzschia ritscheri & 53.1 & 41.7 \\
\hline NIHEI & Nitzschia heimii & 51.6 & 25.0 \\
\hline $\mathrm{CHCON}$ & Chaetoceros convolutum & 46.9 & 58.3 \\
\hline POPSE & Porosira pseudodenticulata & 39.1 & 75.0 \\
\hline CHCAS & Chaetoceros castracanei & 39.1 & 50.0 \\
\hline CHDIC & Chaetoceros dichaetum & 37.5 & 66.7 \\
\hline THGRCVEX & Thalassiosira gracilis var. expecta & 14.1 & 75.0 \\
\hline
\end{tabular}

as percentages (proportionate abundance) of the total valves enumerated. Two small Nitzschia species (N. cylindrus (Grunow) Hasle and $N$. pseudonana (Hasle) Hasle) were found incorporated into tintinnid loricas at several Agulhas stations. The two species were omitted, and proportionate abundances adjusted accordingly, only for comparison of Biscoe and Agulhas stations.

Relationships among stations' net diatom assemblages were assessed by principal component analysis (PCA) of the species correlation matrix, cluster analysis using an agglomerative averaging algorithm, nearest neighbor discriminant analysis and canonical discriminant analysis procedures (SAS Institute Inc. 1982). Principal component analysis performs best on relatively homogenous data sets with few rare species (Gauch 1982), and was the only procedure available to us for ordination without "a priori" station classification. Thus only those species occurring in $50 \%$ or more of the samples from at least one cruise were retained for analysis (Table 1). Two other editing protocols, selecting the most abundant and selecting the most variable species, produced nearly identical lists, and the resultant data matrices differ little from the one used. Distributions of locally abundant taxa not in multivariate analyses are individually noted.

\section{Results}

\section{Characterization of the Biscoe Net Diatom Assemblage}

Cluster analysis and nearest neighbor discriminant analysis identified five station groupings (Fig. 1). The northern sectors (5 and 6 ) are separated from the south-
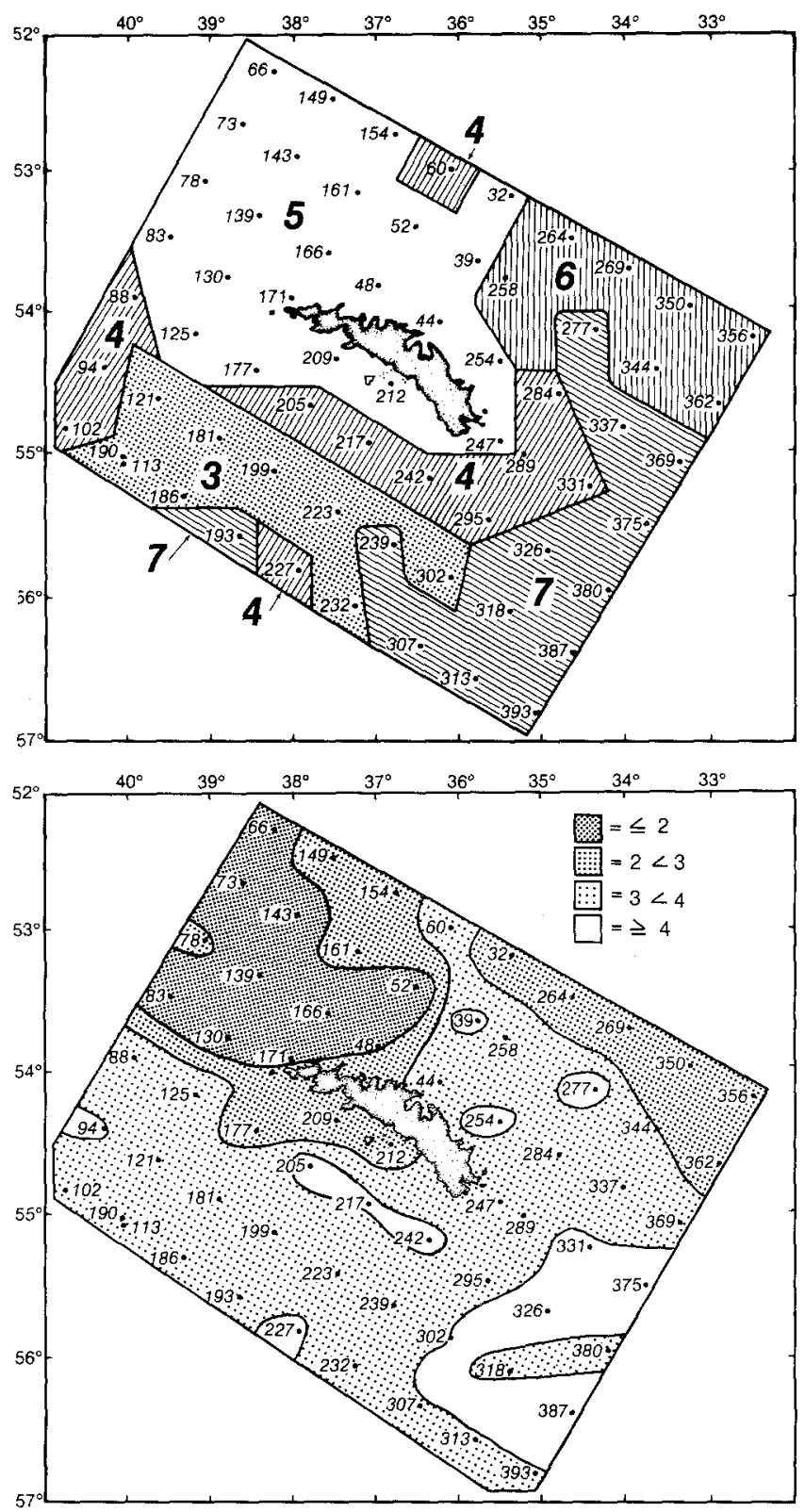

Fig. 1. Station grid near South Georgia sampled by the R.R.S. John Biscoe during November and December 1981. Above, Biscoe sectors $3-7$ as determined by cluster and nearest neighbor discriminant analysis of species occurring in more than half of the Biscoe net tows. Below, Shannon species diversity index values. Contour intervals are given in the top right of the figure

ern (3, 4, and 7) along the first principal component axis (JBPCA 1); within each of the north and south regions, sectors are arranged along JBPCA 2 (Fig. 3). Individual sectors can be resolved in species space by canonical discriminant analysis (Fig. 4). The sectors can each be characterized by one or a few diatom species (Fig. 3), although any species may not be entirely restricted to one sector or, conversely, a characteristic species may not occupy all stations within its sector.

Beginning from the north, sector 5 is a diverse group of stations tied together by overlapping ranges of four 


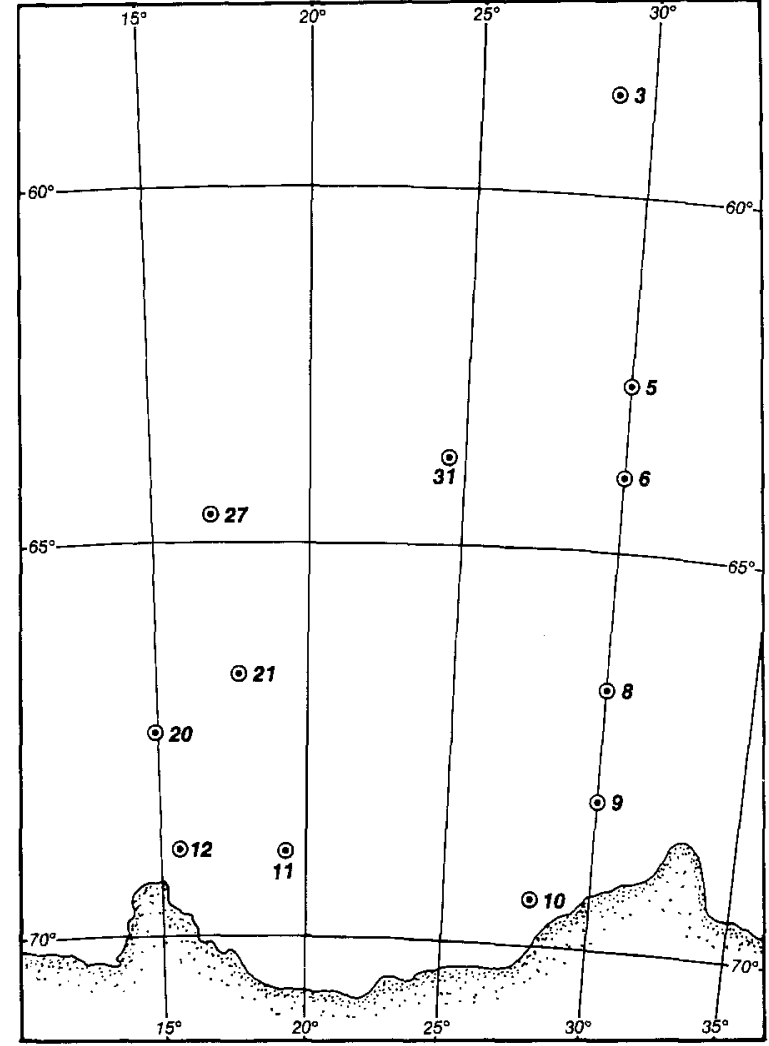

Fig. 2. Selected stations north of Antarctica sampled by the S.A. Agulhas during February and March 1981

so-called neritic species. It is an area of low to moderate species diversity (Fig. 1), and species distributions within 5 can be related to variation in diversity within the sector.

Thalassiosira scotia G. Fryxell and Hoban is proportionately most abundant in areas of 5 with higher species diversity (Figs. 1 and 5). This species was described from S. Georgia waters from areas of high total cell density (Fryxell et al. 1979), and occurs in abundance in a sample with high cell density in this study (over $2,000,000 \mathrm{c} / 1$ at station 209). Resting spore valves, rudimentary valves and vegetative valves (Fryxell et al. 1979) of this species were observed. Resting spores were generally few except at stations 209 and 212. Because these stations were sampled about two weeks later than those with the first occurrence of $T$. scotia, it is tempting to believe that stations 209 and 212 represent the end of growth of this species for the season in this sector. Alternatively, an abundance of resting spores may indicate conditions of the spatial and ecological limit of this species.

Hart (1942) reported the presence of T. antarctica Comber at S. Georgia. This species and T. scotia are highly similar in morphology (Fryxell et al. 1979, 1981), and it is likely that Hart (1942) and we are referring to the same taxon considering that $T$. scotia was found in abundance in the same region in different years.

The low diversity found in the northern most part of sector 5 is due to high proportionate abundance of Chae-
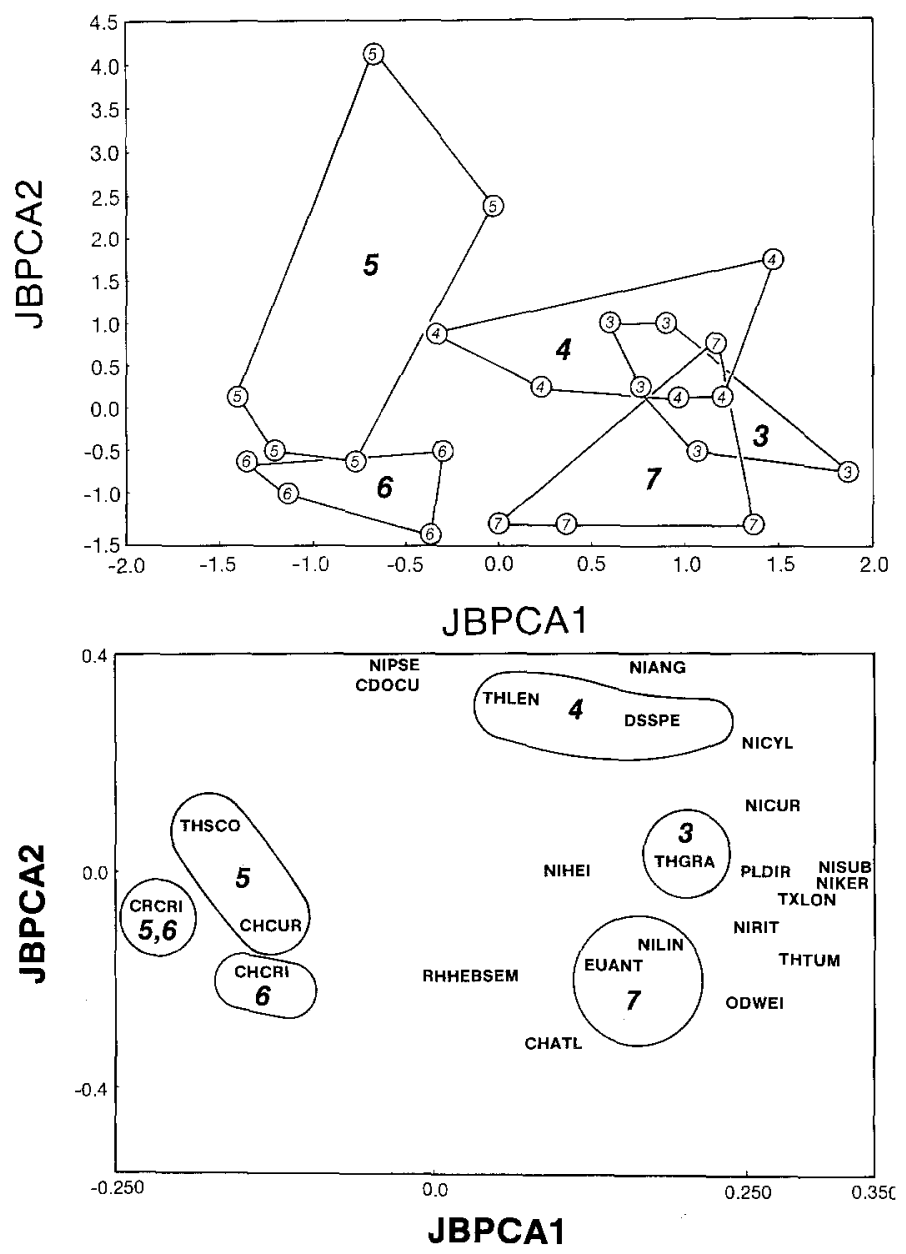

Fig. 3. Principal component analysis of correlation matrix of 24 most frequently occurring species at Biscoe stations. The first principal component axis, JBPCA1, accounts for $25 \%$, and JBPCA2 for $15 \%$, of the variance in the data set. Above, plot of station scores on JBPCA1 and JBPCA2. Only the outliers of each sector are identified and connected. Below, plot of Biscoe species coefficients on JBPCA1 and JBPCA2. Species circled are those judged most characteristic of particular sectors by individual species plots. Species codes are as in Table 1

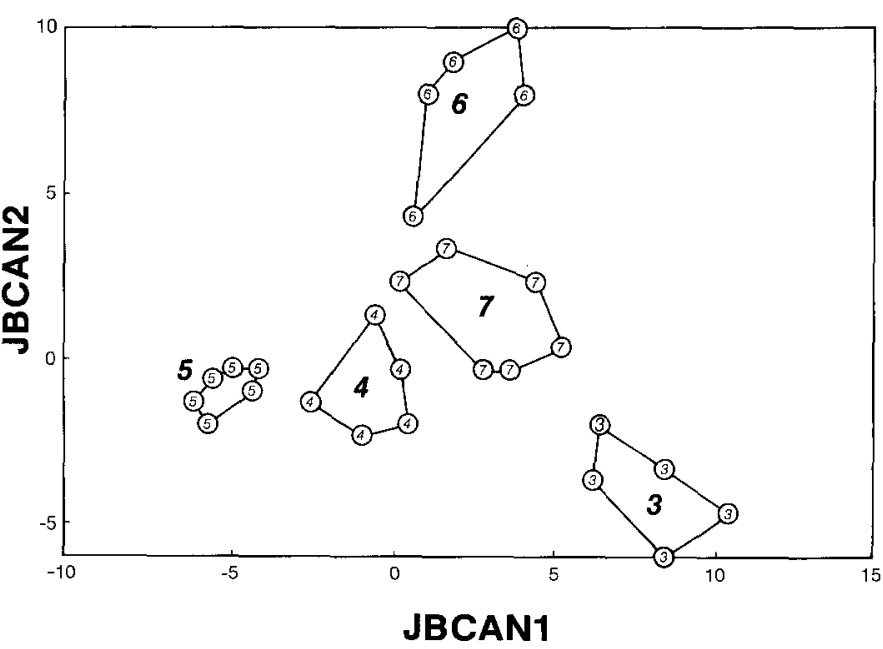

Fig. 4. Plot of Biscoe station scores on first two canonical discriminant axes derived from analysis of 24 most frequently occurring species at Biscoe stations (JBCAN1 and JBCAN2); only outliers of each sector are identified and connected 

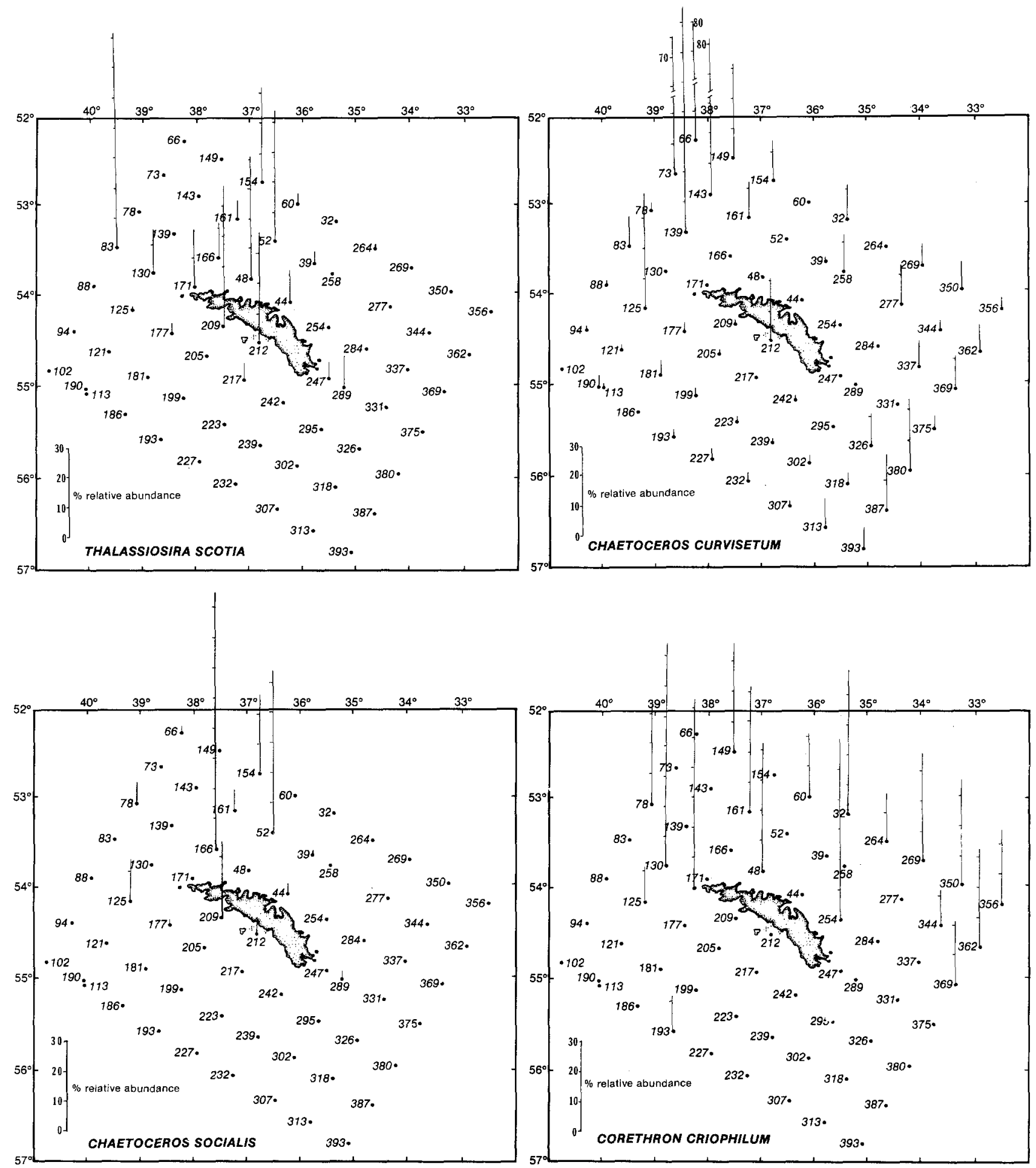

Fig. 5. Distribution of selected diatoms characteristic of waters north of South Georgia, November - December 1981. Occurrences greater than 10\% are plotted for Corethron criophilum; occurences greater than $1 \%$ are plotted for other species

toceros curvisetum Cleve (Fig. 5). This species also occurs in moderate abundance at many Biscoe offshore stations outside of sector 5. Chaetoceros socialis Lauder was not used in the multivariate analysis (only $28 \%$ frequency of occurrence over all Biscoe stations). As is $T$. scotia, C. socialis is proportionately abundant at stations of moderate overall diversity (Figs. 1 and 5). Both $C$. curvisetum and $C$. socialis are considered neritic, temperate species (Cupp 1943; Hendey 1964; Drebes 1974). Corethron criophilum Castracane is abundant at several stations in 5 , but is also proportionately abundant in sector 6 (Fig. 5). 

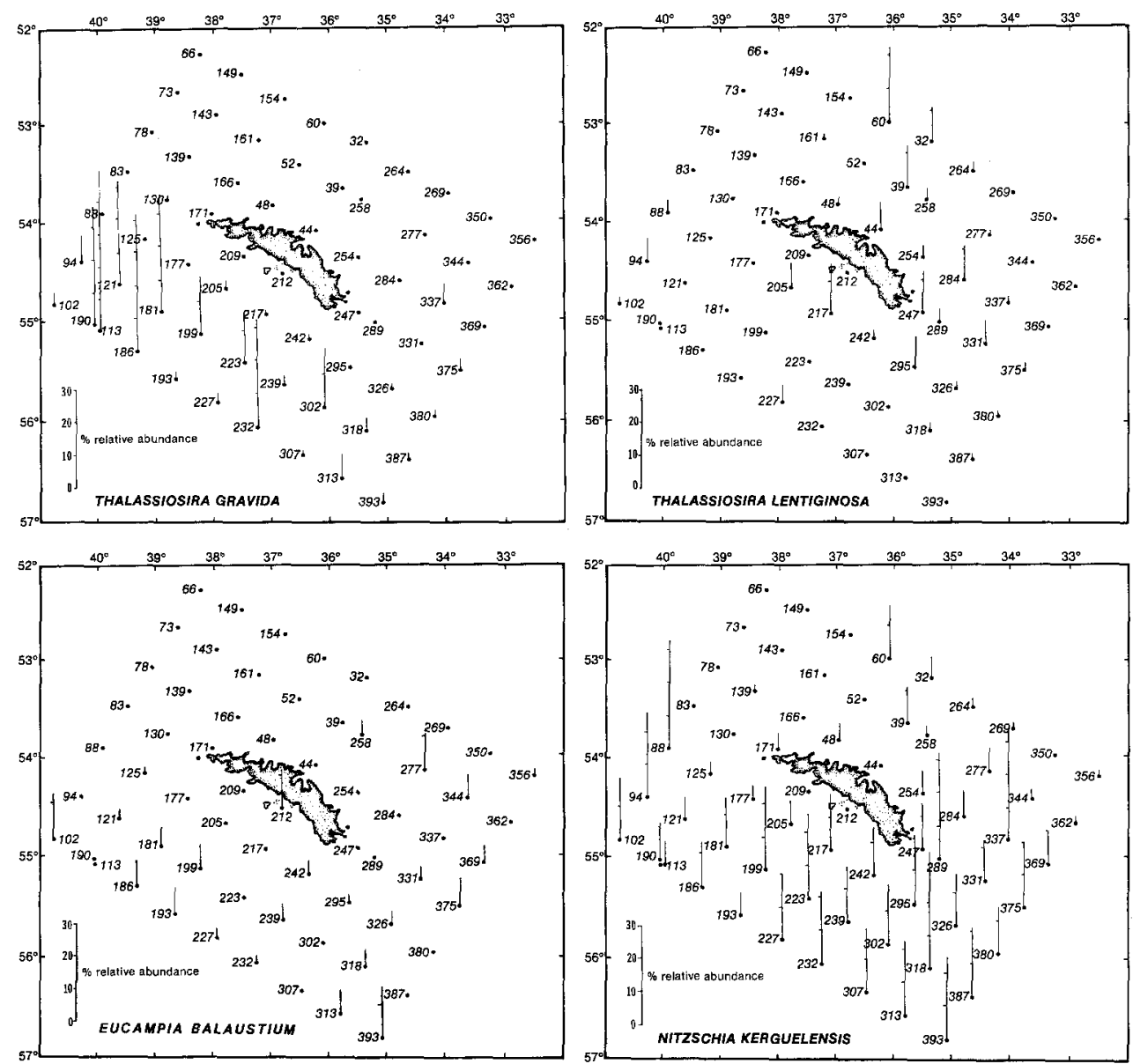

Fig. 6. Distribution of selected diatoms characteristic of waters south of South Georgia, November-December 1981. Occurrences greater than $1 \%$ are plotted

Sector 6 is characterized by the high average proportionate abundance $(34 \%)$ of Chaetoceros criophilum Castracane; the species exceeds $10 \%$ proportionate abundance in only two stations outside of sector 6 . There are conflicting views in the literature of its distribution, perhaps a result of wide tolerance of environmental conditions. However, another factor may be that the identification of $C$. criophilum and similar species is problematical (Fryxell and Medlin 1981). It reportedly tends to increase in importance southward (Hart 1942; Hasle 1969), although Kozlova (1966) regarded it as subantarctic. Manguin (1960) and Kozlova (1966) regarded this species as oceanic, but Frenguelli and Orlando (1958) consider it neritic, and found it to be especially abundant near S. Georgia.

Sector 3 is characterized by Thalassiosira gravida Cleve (Fig. 6). This species is distributed throughout 3,4 and 7 , but reaches its greatest average proportionate abundance in $3(>30 \%)$. It is virtually absent from the strongly neritic assemblage dominating sector 5, even though it is considered a neritic species (Hasle 1976). However, one of us (GAF) has observed gelatinous colonies of this species in abundance south of S. Georgia in the Scotia Sea at and near the ice edge, far from land, during the austral spring of 1983, suggesting that the S. Georgia population may be derived from oceanic waters north of the pack-ice. Its high proportionate abundance indicates it formed gelatinous colonies in our samples because its diameter (ca. $20-25 \mu \mathrm{m}$ ) is less than the mesh of our nets. Observation of living material (not performed) is necessary to confirm presence of such colonies.

Sector 4 is best characterized by $T$. lentiginosa (Janisch) G. Fryxell and the silicoflagellate, Distephanus speculum (Ehrenb.) Haeckel. These species connect the geographically outlying stations of sector 4 (station 60 , $88,94,102$ and 227) to the central part of the sector (Figs. 1 and 6). The former species is considered oceanic (Kozlova 1966). D. speculum is widespread in the world's oceans, but seems to occur in highest numbers in antarctic waters (Hasle 1969).

Sector 7 is best characterized by Eucampia balaustium Castracane and Nitzschia lineola Cleve (Fig. 6). Although the former species is considered neritic and antarctic in distribution by Kozlova (1966), it is widespread in antarctic waters (Hustedt 1958; Hasle 1969). The latter species was frequently abundant in the Pacific sector of the antarctic waters, except at the ice edge (Hasle 1965). 
Sectors 3, 4 and 7 share several abundant so-called oceanic species, underscoring the division between north and south sectors along JBPCA1 (Fig. 3). Moreover, species distributions give the impression of a water mass curling around the eastern end of S. Georgia (e.g. N. kerguelensis) (O’Meara) Hasle; Fig. 6). This image is reinforced by other species with more restricted distributions and lower proportionate abundance (Fig. 6). The PCA also illustrates this. Sectors 3 and 5 are in geographic proximity but are far apart in species space. However, there it is some intergradation of these sectors through 4 and 7 (Fig. 3).

\section{Comparison of Biscoe and Agulhas Assemblages}

Principal component analysis of the frequently occurring species in both areas provides some separation of Biscoe and Agulhas samples (AGJBPCA; Fig. 7), while species coefficients reveal some patterns of species distributions common to both areas (Table 2). Whether Biscoe or Agulhas, stations to the right of Fig. 7 tend to have higher proportionate abundance of Nitzschia kerguelensis than those on the left, reflecting this species high positive loading on AGJBPCA1 $(>0.25)$. Five other species, each also characterized as oceanic in distribution, share the same pattern of distribution and moderate to high ( $>0.10$ ) positive coefficients on the first two PCA axes (Cupp 1943; Hendey 1964; Kozlova 1966; Hasle 1969).

A second group of eight species has moderate to high positive coefficients on the first axis, but negative coefficients on the second (Table 2). These taxa are higher in proportionate abundance at Biscoe stations. As a group they are difficult to classify, being a mixture of oceanic and neritic forms. Some individual species are likewise difficult to categorize (e.g. E. balaustium, see Hasle 1969).

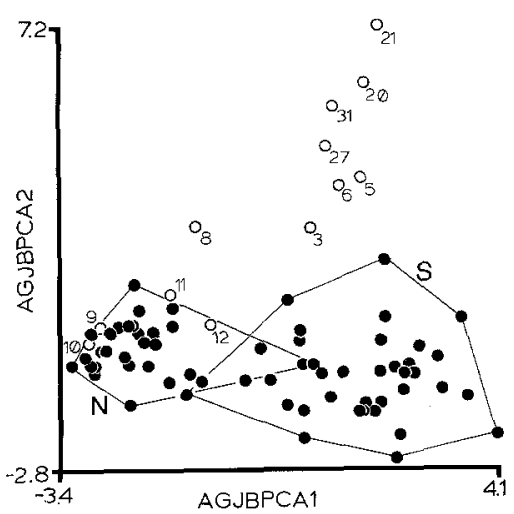

Fig. 7. Biscoe (๑) and Agulhas (O) station scores plotted on first and second principal components derived from analysis of most frequently occurring species (AGJBPCA1 and AGJBPCA2). Each symbol represents at least one station. Individual Agulhas stations are numbered according to Fig. 2. Outliers of pooled northern sectors $(5+6)$ and southern sectors $(3+4+7)$ of Biscoe stations are connected and identified respectively as $(\mathrm{N})$ and $(\mathrm{S})$
Table 2. Principal component analysis of the Biscoe and Agulhas samples pooled. Species coefficients on first two principal component axes (AGJBPCA1 and AGJBPCA2). Based on species occurring in at least half of the samples from at least one cruise, except Nitzschia cylindrus and $N$. pseudonana are excluded. Species proportionate abundances are adjusted as a percentage of total assemblage minus these two Nitzschia species. Species groups are determined from coefficients on the first and second axes, respectively. Group 1 species' coefficients are positive, positive; Group 2 are positive, negative; Group 3 are negative, not loaded $(-0.1<x<0.1)$.

\begin{tabular}{|c|c|c|c|}
\hline \multirow[t]{2}{*}{ Group } & \multirow[t]{2}{*}{ Species } & \multicolumn{2}{|l|}{$\%$ variance } \\
\hline & & $\begin{array}{l}\text { AGJBPCA1 } \\
17\end{array}$ & $\begin{array}{l}\text { AGJBPCA2 } \\
12\end{array}$ \\
\hline 1 & Nitzschia kerguelensis & 0.293 & 0.177 \\
\hline 1 & Nitzschia lineola & 0.192 & 0.276 \\
\hline 1 & Thalassiothrix longissima & 0.212 & 0.294 \\
\hline 1 & Chaetoceros atlanticum & 0.218 & 0.282 \\
\hline 1 & Chaetoceros convolutum & 0.128 & 0.293 \\
\hline 1 & Chaetoceros dichaetum & 0.127 & 0.394 \\
\hline 2 & Thalassiosira tumida & 0.342 & -0.194 \\
\hline 2 & Thalassiosira gravida & 0.152 & -0.158 \\
\hline 2 & Nitzschia sublineata & 0.315 & -0.281 \\
\hline 2 & Nitzschia angulata & 0.111 & -0.133 \\
\hline 2 & Eucampia balaustium & 0.182 & -0.133 \\
\hline 2 & Pleurosigma directum & 0.263 & -0.228 \\
\hline 2 & Nitzschia ritscheri & 0.246 & -0.136 \\
\hline 2 & Odontella weissflogii & 0.303 & -0.184 \\
\hline 3 & Corethron criophilum & -0.268 & 0.006 \\
\hline 3 & Chaetoceros curvisetum & -0.110 & 0.078 \\
\hline 3 & Thalassiosira scotia & -0.224 & -0.069 \\
\hline 3 & Distephanus speculum & 0.133 & 0.087 \\
\hline 3 & Thalassiosira lentiginosa & 0.011 & -0.160 \\
\hline 3 & Rhizosolenia hebetata fo. semispin & ina 0.086 & -0.115 \\
\hline 3 & Chaetoceros criophilum & -0.078 & 0.009 \\
\hline 3 & Nitzschia curta & -0.020 & 0.058 \\
\hline 3 & Coscinodiscus oculus-iridis & -0.065 & -0.069 \\
\hline 3 & Nitzschia heimii & 0.136 & -0.013 \\
\hline 3 & Porosira pseudodenticulata & 0.007 & 0.088 \\
\hline 3 & Chaetoceros castracanei & 0.228 & 0.087 \\
\hline 3 & Thalassiosira gracilis var. expecta & 0.070 & 0.351 \\
\hline
\end{tabular}

Coastal Agulhas stations $(9-12)$ are plotted with northern sector Biscoe stations on the AGJBPCA axes. This is not an artefact of the reduced dimensionality of the PCA analysis. Discriminant analysis also places coastal Agulhas stations with northern sector Biscoe stations and the discriminant axis is highly significantly correlated with AGJBPCA2 $(\mathrm{r}=0.80$, d.f. $=74, P<0.01)$. Taxa held in common by these stations include Corethron criophilum and Chaetoceros curvisetum. The latter species is classified as neritic (Cupp 1943; Hendey 1964); the former reaches its greatest proportionate and absolute abundance in neritic areas (Hart 1942; Frenguelli and Orlando 1958; Cassie 1963; Hasle 1969; Fryxell and Hasle 1971).

\section{Discussion}

Species characterizations and station groupings in the waters of S. Georgia support Hardy's (1967) concept of a 
complex hydrography. Shifts in species assemblages over relatively short distances can approximate the magnitude, if not quality, of changes reported at the Antarctic Convergence zone (Hart 1942; Manguin 1960; Kozlova 1966; Hargraves 1968; Hasle 1969). Areas of precipitous change in the diatom assemblage may reflect abrupt changes in the environment, e.g., areas of contact of water masses with distinct origins containing already present and separately developing assemblages. This is probably especially true of the region just to the west of the island, at the border of sector 5 with the composite sector 3 plus $4(3+4)$. The characteristic species of 5 are neritic, and two of them are considered temperate. Several of the dominants of $3+4$ are reportedly oceanic and antarctic or subantarctic. There is a strong gradient of diversity values near the common border of $3+4$ and 5 . Less sharp change over an area might reflect mixing of water masses, contact of water masses of similar characteristics, and/or species in competition along ecological gradients within a single water mass. Species coefficients and ecological characterizations show a mixture of oceanic and neritic species in the Biscoe stations south of S. Georgia, perhaps indicating an interaction of ocean-derived populations with nearshore effects.

There was some congruence between Hart's (1942) species groupings and species associations in Biscoe samples. For example, many of Hart's group III species are dominants or subdominants in the southern sectors $(3+4+7$, e.g. $T$. gravida). However, Chaetoceros socialis, one of Hart's group III species, is limited to sector 5 in this study. Three of Hart's (1942) group II taxa were dominants in this study: Corethron criophilum, Chaetoceros criophilum and Rhizosolenia hebetata fo. semispina (Hensen) Gran. However, their distributions were not completely congruent. The first taxon had a scattered distribution in sectors 5 and 6, the second was limited almost entirely to sector 6 and the last was moderately abundant throughout nearly the entire S. Georgia area.

A large portion of the literature on antarctic diatoms is devoted to grouping species with similar ecological distributions. Hart (1942) believed that such groups should accurately reflect the "space/time distribution" of the species, and included the season of greatest abundance as one criterion for his species groups. Hasle (1969) recognized a seasonal component to geographic distribution of certain widespread species (subgroups of her group 7), and showed how discrepancies in certain species characterizations could be explained by accounting for season. Season can be considered a set of associated ecological factors.

Similarly, we consider "neritic" or "oceanic" less as geographic locations and more as environmental phenomena consistent enough in their association to be viewed as distinct. Some assemblages at $\mathrm{S}$. Georgia were dominated by so-called neritic species; others, by socalled oceanic species. Species distributions at Agulhas stations independently supported these ecological characterizations. The former species were characteristic of the most landward Agulhas stations; the latter species, of open ocean stations. Our PCA of pooled Agulhas-Biscoe data revealed that this "neritic-oceanic" factor was common to both areas. These similarities occurred in spite of seasonal difference in sampling that may have resulted in differentiation of open ocean Agulhas stations from Biscoe stations. Other named and unnamed ecological factors exist (e.g. depth). Thus, it may be that Hasle's (1969) conclusions on the interplay of season and geography can be generalized to other factors in order to explain apparent discrepancies in species distributions.

Another factor, spatial scale, can also influence species groupings. The pertinent horizontal scale in antarctic waters has been addressed (e.g. Hasle 1969; Kopczynska 1980). Venrick (1982) found discrete assemblages over depths of less than $200 \mathrm{~m}$ in the north Pacific. However, examination of discrete whole water samples revealed no apparent differences in kinds of species with depth in our study areas (unpublished data).

Horizontal scale does have a significant effect on apparent species groupings. In the S. Georgia area, a mosaic of species distributions with varying degrees of overlap was the rule. It is evident that overlap among assemblages could have been less, resulting in more discrete (but more arbitrary) species groupings, had we examined fewer, more widely spaced, stations. This is not a criticism of Hart's groupings, but attempts to make species groupings that fulfill Hart's (1942) ideal of reflecting species "space/time distribution" would do well to recognize that scale in both space and time affects apparent species groupings.

Acknowledgements. M. A. Meyer (Texas A\&M University, TAMU) collected the Agulhas samples in a cooperative program with S. Z. ElSayed (TAMU). British Antarctic Survey (BAS) personnel, especially T. M. Whittaker, collected the Biscoe samples when TAMU personnel were forced to withdraw from the cruise for health reasons. K. R. Buck, W. N. Herzig (both TAMU), T. A. Villareal (University of Rhode Island) and J. R. Johansen (Brigham Young University) provided technical assistance. J. Priddle (BAS) provided valuable comments on the manuscript. This report was supported by National Science Foundation grants DPP-8020381 and DPP-7823463.

\section{References}

Cassie V (1963) Distribution of surface phytoplankton between New Zealand and Antarctica, December 1957. T A E Sci Rep 7:1-11

Cupp EE (1943) Marine plankton diatoms of the west coast of North America. Bull Scripps Inst Oceanogr 5:1-238

Drebes G (1974) Marines Phytoplankton: Eine Auswahl der Helgoländer Planktonalgen (Diatomeen, Peridineen). Thieme, Stuttgart, pp $1-186$

Frenguelli J, Orlando HA (1958) Diatómeas y Silicoflagelados del Sector Antártico Sudamericano. Inst Antart Argent, Publ 5:1-146

Fryxell GA, Hasle GR (1971) Corethron criophilum Castracane: its distribution and structure. In: Llano GA, Wallen IE (eds) Biology of the Antarctic Seas, vol IV. American Geophysical Union, Washington DC (Antarct Res Ser, vol 17, pp 335-346)

Fryxell GA, Medlin LK (1981) Chain forming diatoms: evidence of parallel evolution in Chaetoceros. Cryptogamie: Algologie 2:3-29 
Fryxell GA, Villareal TA, Hoban MA (1979) Thalassiosira scotia, sp. nov.: observations on a phytoplankton increace in early austral spring north of the Scotia Ridge. J Plankton Res 1:355-370

Fryxell GA, Doucette GJ, Hubbard GF (1981) The genus Thalassiosira: the bipolar diatom T. antarctica Comber. Bot Mar 24:321 - 335

Gauch HG Jr (1982) Multivariate analyses in community ecology. Cambridge University Press, Cambridge, pp 1-298

Hardy A (1967) Great waters. Harper and Row NY, pp 1-542

Hardy A, Gunther ER (1935) The plankton of the South Georgia whaling grounds and adjacent waters, 1926-27. Discovery Rep 11:1-486

Hargraves PE (1968) Species composition and distribution of net plankton diatoms in the Pacific Sector of the Antarctic Ocean. Ph D Thesis, College of William and Mary Va

Hart TJ (1942) Phytoplankton periodicity in antarctic surface waters. Discovery Rep 21:261 - 356

Hasle GR (1965) Nitzschia and Fragilariopsis species studied in the light and electron microscopes. 2. The genus Fragilariopsis. Skr Norske Vidensk Akad I Mat-Nat K1 N S 21:1-45

Hasle GR (1969) An analysis of the phytoplankton of the Pacific Southern Ocean: abundance, composition, and distribution during the Brategg Expedition, 1947-48. Hvalradets Skr 52:1-168

Hasle GR (1976) The biogeography of some marine planktonic diatoms. Deep-Sea Res 23:319-338

Hendey NI (1937) The planktonic diatoms of the southern seas. Discovery Rep 16:151 - 364

Hendey NI (1964) An introductory account of the smaller algae of
British coastal waters. 5. Bacillariophyceae (Diatoms). London, Her Majesty's Stationery Office, pp 1-317

Hustedt F (1958) Diatomeen aus der Antarktis und dem Südatlantic. Dtsch Antarkt Exp 1938/39 2:103 - 191

Karsten G (1906) Das Phytoplankton des Atlantischen Ozeans nach dem Material der Deutschen Tiefsee-Expedition 1898-99. Wiss Ergebn Dtsch Tiefsee-Exp Valdivia 1898-99, 2:137-219

Kopezynska EE (1980) Small scale vertical distribution of phytoplankton in Ezcurra Inlet (Admiralty Bay, South Shetland Islands). Pol Polar Res 1:77-96

Kozlova OG (1966) Diatoms of the Indian and Pacific sectors of the Antarctic (English translation). NSF, Washington DC, S Monson, Jerusalem, $p p 1-191$

Mangin L (1922) Phytoplancton antarctique. Mem Acad Sci Paris $57: 1-134$

Manguin E (1960) Les diatomées de la Terre Adélie. Campagne du Commandant Charcot 1949-1950. Ann Sci Nat Bot 12:223-363

SAS Institute Ine (1982) SAS user's guide: statistics, 1982 edn. Ray AA (ed) SAS Institute Inc, Cary NC, pp 1-584

Simonsen R (1974) The diatom plankton of the Indian Ocean expedition of the RV Meteor 1964-1965. Meteor Forsch-Ergeb 19:1-66

Van der Spoel S, Hallegraeff GM, Van Soest RWM (1973) Notes of variation of diatoms and silicoflagellates in the South Atlantic Ocean. Neth J Sea Res 6:518-541

Venrick EL (1982) Phytoplankton in an oligotrophic ocean: observations and questions. Ecol Monogr 52:129-154 